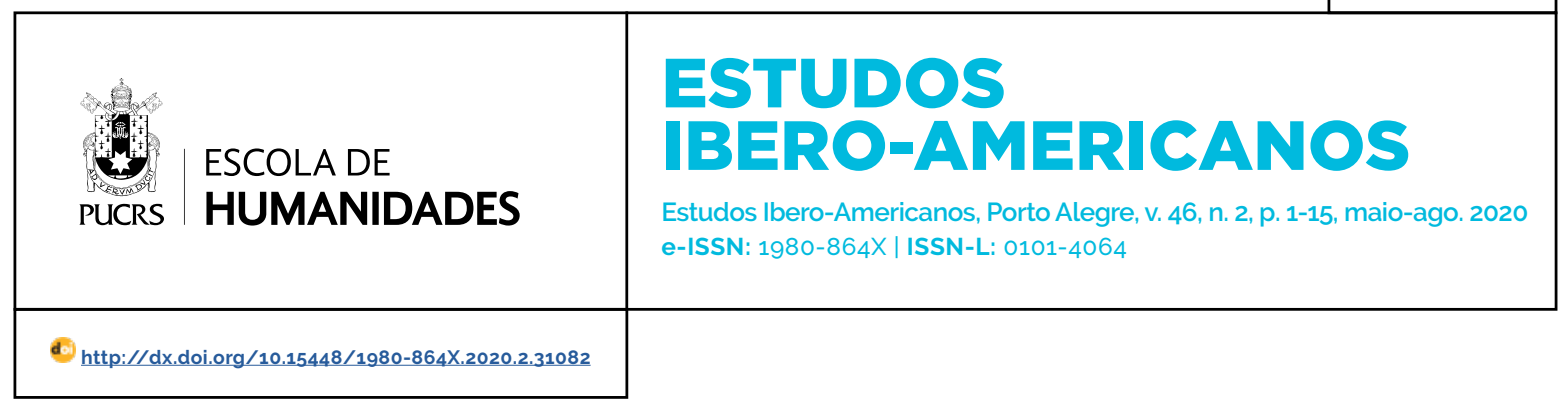

SEÇÃO LIVRE

\title{
Discursos memoriais lusitanos: representação e instrução das elites (século XVII)
}

\author{
Lusitanian memorial discourses: representation and instruction of the elites (17th century) \\ Discursos memoriales lusitanos: representación e instrucción de las elites (siglo XVII)
}

\section{Guilherme Amorim de Carvalho ${ }^{1}$}

orcid.org/0000-0003-3554-2259

quilhemrejawa@hotmail.com

Recebido em: 15 jun. 2018

Aprovado em: 15 out. 2019.

Publicado em: 25 ago. 2020.

\section{(c) (1)}

Artigo está licenciado sob forma de uma licença Creative Commons Atribuição 4.0 Internacional.
Resumo: O presente artigo analisa um conjunto de discursos de caráter memorial, como sermões fúnebres, panegíricos, tratados, crônicas e epítomes - escritos ao longo do século XVII em Portugal e algumas de suas conquistas. Com base nesses documentos, pretendeu-se interpretar a maneira como as elites do reino e das conquistas compreendiam-se a partir das representações retórico-poéticas da ordem política, interpretando suas disposições hierárquicas e espaciais com base em concepções aristotélico-tomistas que, em larga medida, forneciam os fundamentos dos ideais de nobreza e poder régio, adotados tanto pelas elites locais quanto pelos nobres da Corte.

Palavras-chave: Discurso. Nobreza. Elite. Poder.

Abstract: The present article analyzes a set of memorial speeches, such as funeral sermons, panegyrics, treatises, chronicles and epitomes - written throughout the seventeenth century in Portugal and some of its conquests. Based on these documents, the intention was to interpret the way in which the elites of the kingdom and of the conquests understood themselves through the rhetoric-poetic representations of the political order, interpreting its hierarchical and spatial dispositions on the basis of Aristotelian-Thomist conceptions, which broadly provided the foundations of the ideals of nobility and royal power, adopted by both: the local elites and the nobles of the Court.

Keywords: Discourse. Nobility. Elite. Power

Resumen: El presente artículo analiza un conjunto de discursos de carácter memorial, como sermones fúnebres, panegíricos, tratados, crónicas y epítomes - escritos a lo largo del siglo XVII en Portugal y algunos de sus conquistas. Con base en estos documentos, se pretendió interpretar la manera como las élites del reino y de las conquistas se comprendian a partir de las representaciones retórico-poéticas del orden político, interpretando sus disposiciones jerárquicas y espaciales con base en concepciones aristotélico-tomistas que, en larga medida, proporcionaban los fundamentos de los ideales de nobleza y poderio regio, adoptados tanto por las elites locales como por los nobles de la Corte.

Palabras clave: Discurso. Nobleza. Élite. Poder.

\section{Introdução}

Denominamos "discursos memoriais" composições de natureza retóricopoética inseridas no gênero discursivo demonstrativo, ou epidictico, tais como crônicas, panegíricos, sermões e demais composições poéticas. Isto é, são obras cuja motivação principal é o elogio ou vitupério de um personagem que obteve destaque perante o restante da comunidade 
na qual se insere ou esteve inserido. Nesse tipo de discurso, não se pretende convencer o auditório acerca de verdades especulativas, mas intensificar a adesão desse a preceitos morais efetivos. Tendo isso em vista, o discursista busca criar um consenso em torno de valores reconhecidos pelo público receptor, por meio de um instrumental retórico que the permite ampliar e fortalecer tais valores (PERELMAN; OLBRECHTS-TYTECA, 1996, p. 53-54).

Com base nessa perspectiva, o presente artigo traz a análise de uma série de discursos memoriais, difundidos ao longo do século XVII na monarquia lusitana e alguns de seus territórios anexos, a partir de suas representações ideais de nobreza. ${ }^{2}$ Em vista disso, o que se pretendeu foi perceber e interpretar o referencial teológicopolitico que orientava a construção de tais discursos e que contribuiam para fundamentar as representações da ordem social.

De acordo com Hansen, sob a ótica do "barroco histórico", o qual não deixa escapar de vista as especificidades teológico-políticas das representações retóricas, os textos aos quais chamamos discursos memoriais estavam associados a programas especificos das instituições ibéricas, que visavam assegurar o controle do monarca sobre as redes de administração da Coroa, espalhadas pelos diversos territórios da monarquia (HANSEN, 2008, p. 200-210).

Nesse sentido, a representação hierárquica da organização político-social surge nos discursos como unidade de integração, que buscava conformar as instituições e processos administrativos das localidades. Assim sendo, tais discursos reproduziam representações hierárquicas e práticas políticas da Corte nos territórios mais afastados, prescrevendo as posições sociais por meio de imagens, a partir das quais os leitores deveriam se reconhecer, persuadindo-lhes a permanecer em sua posição subordinada ao bem-comum do corpo-social (HANSEN, 2008, p. 200-210).

Entretanto, para levar a cabo a análise dos discursos memoriais selecionados, propomo-nos a interpretá-los à luz de uma concepção "naturalistacorporativa" da sociedade portuguesa moderna, segundo a qual a ordem social era composta por diversos grupos relativamente autônomos, com fins específicos e que formavam um todo coerente. Dessa forma, cada grupo social, ou corporação, necessitava de um estatuto concreto (direito), ou subjetivo (costume, tradição) diferente, que the garantisse a liberdade para cumprir sua finalidade natural (HESPANHA, 2001, p. 3).

Consequentemente, a população não esperava, tampouco desejava, mudanças na organização político-social. As ações governativas do monarca deveriam observar a manutenção, tanto das normas positivas quanto dos direitos naturais e tradicionais relativos a cada parte que compunha o todo do corpo social, caso contrário, tais ações seriam consideradas ilegitimas perante os cidadãos, independentemente de suas posições hierárquicas (CARDIM, 1998, p. 145).

Dessa forma, ainda que os discursos memoriais fizessem parte de um processo de comunicação articulado pelas elites políticas e religiosas, com o objetivo de obter a adesão do público receptor ao modelo de organização político-social e a determinadas pretensões dos governantes, não era apenas o monarca e a elite nobiliária que demandavam representações exemplares acerca das formas adequadas de exercício do poder político, mas também a população de modo geral (SORIA, 1988, p. 196-197).

Cada grupo social esperava encontrar nos discursos memoriais um repertório de crenças básicas, amplamente compartilhadas, acerca das formas adequadas de exercício do poder político, o que permitia aos homens compreenderem-se como parte da organização político-social. Nesse

\footnotetext{
2 Assim como Hansen, designamos por "Século XVII", a duração da "política Católica" da colonização ibérica, antimaquiavélica e antirreformista, cujos limites propostos são o início da União lbérica (1580), e a morte de Dom João V (1750), em conjunto com as transformações políticas implementadas pelo Marquês de Pombal. No entanto, gostariamos de ressaltar que tais datas são marcos indicativos, e que a delimitação do recorte temporal ao qual chamamos de século XVII é um tanto flexível, podendo ser recuada, e podendo abarcar referências e modelos político-sociais inseridos em uma longuíssima duração, de origem medieval ou tardo-medieval, e que ainda contribuia para a conformação do imaginário político-social das monarquias ibéricas (HANSEN, 2008, nota 1).
} 
sentido, os discursos memoriais funcionavam como vias de mediação entre a monarquia e o juizo do público receptor a respeito de suas posições no escalonamento hierárquico da sociedade e estavam direcionados para responder às demandas de ambas as partes (SORIA, 1988, p. 198-199).

Compreendemos por ideal de nobreza um conjunto de qualidades distintivas atribuidas aos que ocupavam as posições mais altas na ordem social e aos que eram considerados os melhores de cada comunidade. Nesse sentido, consideramos nobres todos aqueles detentores de um estatuto social que lhes permitia distinguirse da plebe, exercendo funções relativas ao governo, à administração, ou à milícia. Isso não se traduzia, necessariamente, na posse formal de um título de nobreza. Portanto, esse ideal nobiliário era perseguido tanto pela nobreza de linhagem sanguinea, como pela pequena nobreza, ou "nobreza da terra". Nessa perspectiva, o ideal de nobreza apresentado pelos discursos memoriais contribuía para a formação de um "ethos nobiliárquico" português do Antigo Regime, que influenciava, modelarmente, as práticas institucionais e discursivas que se desenvolviam nas sociedades das conquistas lusitanas (MONTEIRO, 2005, p. 5).

Desse modo, para levarmos a cabo a análise dos principios e valores da nobreza lusitana seiscentista, a partir de seu referencial retórico, selecionamos um amplo corpo documental, que reúne sermões fúnebres e alguns outros discursos encomiásticos publicados ao longo do século XVII.

Com base nessa documentação, nossa interpretação privilegia as representações retórico-políticas acerca das relações entre o poder da nobreza e o poder régio, a partir do pensamento aristotélico-tomista, predominante na Península Ibérica no periodo pós-tridentino. Os autores dos discursos analisados buscam representar as relações de poder por meio de adaptações da teoria aristotélica das causas segundas e do conceito tomista de participação. De acordo com tais ideias, todo efeito possuia um determinado grau de participação em sua causa. Sendo o rei a causa do poder dos nobres, eles eram considerados corresponsáveis pela administração da Coroa, possuindo deveres morais, sociais, políticos e religiosos semelhantes, associados ao exercicio da justiça e da realização de feitos virtuosos a serviço do bem-comum do reino e da fé Católica.

\section{Uma "nobreza" intermediária}

Como aponta Hespanha, a ordenação hierárquica da sociedade no Antigo Regime português não ocorria por decreto real, ou diretamente por via do poder econômico, tampouco por critérios estritos de nascimento, mas, sobretudo, em função do exercicio "natural" das diversas atividades, papéis sociais, ou oficios militares e político-administrativos. Os critérios de sangue e nascimento, embora possuissem um papel central no escalonamento da sociedade, não eram, na prática, estritamente determinantes, como aconteceria em uma sociedade de castas (HESPANHA, 1982, p. 221).

Nuno Monteiro ressalta que na modernidade ibérica, a nobreza passa a significar mais uma qualidade do que uma função ou oficio. O conceito de qualidade dizia respeito à "qualidade de nascimento" e, portanto, remetia-se ao estatuto que cada um possuia mesmo antes de nascer. Isso permitia uma distinção entre uma nobreza natural e outra nobreza, adquirida por outras vias que não o nascimento. Desse modo, durante o Antigo Regime português, as representações sociais não se esgotavam apenas na oposição nobre/plebeu, mas também era possivel distinguir os fidalgos, uma categoria sempre mais restrita, ligada à hereditariedade da qualidade de fidalgo, e graus menores de nobreza, relacionados a diversas funções e ofícios (MONTEIRO, 2005, p. 5-8).

Francisco Xavier da Serra Craesbeeck, em seu manuscrito Espelho da nobreza do Reyno de Portugal, defende a existência de dois tipos de nobreza: a de sangue, ou de origem, e a civil, ou política. A nobreza de sangue era fundamentada por uma longa sucessão hereditária de familias, as quais possuiam antepassados que haviam se tornado ilustres em virtude de grandes feitos "em armas, ou letras, ou outro exercício honesto". 
Nesse tipo de nobreza, a glória obtida pelos ascendentes era transmitida aos descentes, por via hereditária, para que esses a conservassem. A nobreza civil, segundo o autor, era aquela que provinha do exercício de um cargo nobre da república, alcançado por meio de mercê régia, concedida em retribuição de serviços prestados e não necessariamente pela sucessão de sangue, podendo o titular possuir ou não antepassados renomados (CRAESBEECK, [17--?], p. 4, 5).

Ainda na concepção de Francisco Craesbeeck, a nobreza era composta por duas partes: antiguidade e clareza. A antiguidade dizia respeito à duração da reputação de um homem enquanto nobre. Portanto essa caracteristica associava-se à linhagem de sangue, haja vista que a fama de nobre não derivava apenas das próprias ações, mas também dos grandes feitos dos antepassados. A segunda parte que compunha a nobreza, a clareza, correspondia às qualidades dos oficios desempenhados dentro da república, assim como pelos senhorios de terra e posse de títulos. A clareza, além de ser evidenciada pelos requisitos citados anteriormente, deveria ser confirmada por meio do exercício de certas virtudes, como "letras, valor, lealdade, fidelidade e justiça" (CRAESBEECK, [17--?], p. 1).

Segundo a opinião de Craesbeeck, a clareza possuía uma relativa preeminência sobre a antiguidade para a constituição da nobreza, pois a linhagem hereditária, o exercício de um cargo, e a posse de terras ou títulos não compunham, por si só, a qualidade de nobre. Para ser considerado realmente membro da nobreza era necessária a adoção de valores e condutas que confirmassem, perante a sociedade, o merecimento da condição de nobre (CRAESBEECK, [17--?], p. 1). É possivel que fosse a partir dessas lógicas que as elites locais da monarquia portuguesa, mesmo quando não possuiam considerável antiguidade, julgavam-se nobres por sua clareza perante as sociedades nas quais viviam.

Em uma perspectiva semelhante, João de Medeiros Correia ${ }^{3}$, ao iniciar seu panegírico ao mestre de campo general da provincia do Alentejo, André de Albuquerque Ribafria, afirma que "a nobreza acquirida pello braço, se deva preferir à hereditaria", entretanto, mais à frente o autor faz a seguinte ressalva: ainda que "I...] na opiniam de Seneca, sò dos proprios merecimentos se deva fazer cazo, nam podemos negar que assentam sobre o illustre do sangue com mais decoro as glorias [...]". Isto é, para Correia, os feitos valorosos para o bem do real serviço se fundamentavam de maneira mais adequada naqueles que possuiam uma nobreza hereditária. Portanto, vale ressaltar que essa aparente preeminência da clareza sobre a antiguidade, ou dos "merecimentos" sobre o "sangue", não corresponde imediatamente a uma atualização dos valores nobiliárquicos, que afirmaria a superioridade do "mérito individual" à tradição e à hereditariedade como principais elementos que compunham a nobreza de um súdito (MONTEIRO, 1997, p. 384).

Deve-se considerar nessa questão, a segunda parte que compunha o atributo que Craesbeeck denomina clareza, ou seja, para além dos oficios, títulos e posse de terras, a clareza deveria ser evidenciada pelo exercício de virtudes correspondentes ao ideal de nobreza. Tais virtudes deveriam ser demonstradas publicamente, haja vista que, segundo o autor, a palavra nobre significa "conhecido" e, portanto, a nobreza estava relacionada às notícias que se possuía acerca de algo ou alguém (CRAESBEECK, [17--?], p. 1).

Percebe-se que a demonstração pública da clareza se aproximava do conceito de fama. A fama pública consistia na prática diuturna de se viver de maneira honrada, sendo a honra considerada a maneira de se comportar em diversos âmbitos, de acordo com a própria distinção hierárquica, assim como de agir adequadamente perante a dignidade de outrem, isto é, a honra estava relacionada ao respeito pelo decoro hierárquico. Tal demonstração constante de respeito pelas distinções sociais produzia a estima pública, confirmando a legitimidade da posição social ocupada. Nesse sentido, a fama pública era um

\footnotetext{
3 Medeiros Correia foi Auditor Geral do Exército da Província do Alentejo, provavelmente entre 1644 e 1659, ano que ocorreu a Batalha das Linhas de Elvas (CORREIA, 1659, Dedicatória)
} 
critério de avaliação que decidia publicamente se um homem deveria ser considerado nobre (HESPANHA, 2006, p. 132-134).

O bacharel em teologia e direito, António Carvalho de Parada, em seu tratado impresso em 1627, chamado Discurso politico fundado en la doctrina de Christo Nuestro Señor, y de la Sagrada Escritura, defende que a honra, em termos políticos, é um atributo exterior, pois somente se pode chamar de honrado, aqueles que possuiam fama de homens honrados. Tal fama dependia, na ordem que coloca o autor, das obras de valor, do sangue ilustre e da ocupação de um lugar de preeminência na hierarquia social. Apesar dessas três características serem complementares, António de Carvalho argumenta que os feitos virtuosos devem ser mais estimados na composição de uma reputação honrada, pois ao não obrar, ou obrar de maneira desonrada, mesmo um grande monarca poderia comprometer tanto sua nobreza hereditária, como o ofício régio (PARADA, 1627, p. 6-6 (v)).

Ao interpretar os discursos citados anteriormente é possivel perceber que mais do que diminuir a importância do sangue para a composição da nobreza, pretendia-se evidenciar a indispensabilidade do serviço, da reputação, da fama e da honra para a legitimação da posse de um estatuto de nobreza. Nessa perspectiva, a valorização do "mérito" estava relacionada à possibilidade de o nobre ser destituído de sua nobreza, caso não obrasse feitos de valor a serviço da Coroa e da fé Católica. Contudo a realização de feitos de valor, também chamados empresas, deveriam seguir um decoro hierárquico. Era necessário que a ação empreendida fosse ajustada à condição ou qualidade (estado natural) do protagonista. Dessa maneira, em princípio, somente aqueles que possuíssem um status social distinto eram dignos de levar a cabo uma ação virtuosa a serviço da Coroa e do bemcomum do reino (ANDRADE, 2008, p. 55).

Segundo essa representação discursiva do escalonamento nobiliário, quanto mais "qualificado" fosse o nobre, mais autorizado ele estava para prestar os serviços de mais importância para o reino e, dessa forma, angariar as mercês régias mais vantajosas. Aos menos qualificados, sobravam os feitos menores, retribuidos por mercês de menor monta. Assim, formava-se uma nobreza cujo prestígio e o poder político eram distribuídos descendentemente pelo monarca, da fidalguia aos graus menores de nobreza, ou "estados privilegiados".

É interessante notar que, mesmo nas localidades, havia uma distinção entre a primeira nobreza e uma nobreza "intermediária", como sugere o trecho de uma resolução do rei Dom Pedro II, de 1686; citada por Thiago Krause, na qual o monarca decide que

na Bahia não se faça eleição de nenhum dos cavaleiros das três Ordens para ofício de procurador, visto que para estes cargos se não costuma eleger as pessoas da primeira nobreza, que servem de juizes e vereadores, se não outras de diferente qualidade (KRAUSE, 2014, p. 217).

Percebe-se, a partir dessa passagem, a preocupação do monarca em manter o decoro hierárquico da sociedade da Bahia, assim como a distinção conferida pelos hábitos das Ordens Militares, as quais eram tuteladas pela Coroa. Os cavaleiros das três Ordens eram pessoas que deveriam, em princípio, possuir certa qualidade e, consequentemente, não poderiam servir aos cargos camarários mais baixos, como o de procurador, sem incorrer na depreciação do valor nobilitante do hábito, assim como na subversão da ordenação natural daquela sociedade. Entretanto, nas conquistas, a obtenção de títulos e distinções nobiliárquicas superiores da monarquia foi quase impossibilitada para as elites locais. Consequentemente, a constituição de uma classe privilegiada, conhecida como nobreza da terra (em distinção à nobreza do reino), contou com o acesso a cargos camarários como mecanismos de nobilitação, de obtenção de privilégios e, sobretudo, de negociação com o centro político da monarquia (BICALHO, 2005, p. 29).

Seguindo por esse viés, o abade Bernardo de Braga, em seu manuscrito Sentimentos publicos de Pernambuco na morte do Infante D. Duarte (1651), interpela seu auditório acera do falecimento do infante, irmão de Dom João IV, da seguinte maneira: 
Nam vedes o Mestre de Campo General de todo estado do Brasil todo enlutado. Nam vedes todos esses Mestres de Campo, Tenentes, Generaes, Sargentos Mayores, Capitaens, Ajudantes, Infantaria, Nam vedes toda a Nobreza desta Capitania cuberta de trevas de dò? (BRAGA, 1651).

Nota-se que o autor circunscreve a nobreza da terra aos homens que ocupavam cargos militaradministrativos. Uma das razões para isso era que em regiões ultramarinas conflituosas, como Pernambuco no contexto das invasões holandesas, os membros da comunidade reconheciam como nobres, aqueles que dispunham seus serviços para a conquista e a conservação de territórios em nome da Coroa. Isto é, tais homens justificavam seu status social mais em função da qualidade de conquistadores e de defensores a serviço da Coroa, do que estritamente pela linhagem de sangue (FRAGOSO; GOUVÊA; BICALHO, 2000, p. 77. 78). No entanto, no título do manuscrito, lê-se o seguinte acerca do sermão: "assistindo o Mestre de Campo General de todo o Estado do Brasil Francisco Barreto, Governador das armas desta Capitania, com a camera \& mais Nobreza". Ou seja, para Bernardo de Braga, além de Francisco Barreto de Meneses, que na ocasião ocupava o cargo de "Mestre Campo General", os membros da câmara também eram considerados nobres.

Prosseguindo com a questão das elites locais, António Gil Preto, no seu manuscrito intitulado Sentimentos Pella morte do Principe Dom Theodosio (1654), utiliza-se do termo "magistrado" para referir-se aos homens principais da cidade de Goa. De acordo com ele, "Governavão o Civil e Político da Republica, formando o Magistrado della, pela vereação do anno prezente, os idoneos, e capazes sogeitos em que o cuidado de todos se benefficiava" (PRETO, 1654, p. 18).

Como sugere a passagem citada, os magistrados não eram apenas autoridades jurídicas, mas também governavam o "civil e político" da cidade, ou seja, mediavam tanto as relações entre particulares, quanto as relações entre esses e os poderes públicos (HESPANHA, 1982, p. 211). Desse modo, nos diversos territórios portugueses, os magistrados das câmaras possuíam atribuições que compreendiam a jurisdição em primeira instância de quase todas as matérias relativas à administração da comunidade. Portanto, devido a sua importância na vida local, os ofícios camarários eram capazes de conferir distinção social aos seus agentes (MONTEIRO, 1998, p. 270).

Além dos magistrados, Lopes Sierra, em seu Panegírico Fúnebre a D. Afonso Furtado (1676), ao dirigir-se ao seu auditório, inclui entre os "Nobilissimos Brasilienses" da Bahia, o "Nobre Eclesiástico e secular cabido", assim como os "cavaleiros e homens bons" (SIERRA, 1676, p. 8182). A utilização do termo "nobreza" para designar as elites locais, também aparece nos documentos oficiais, como aponta Thiago Krause, ao citar uma provisão do rei Afonso VI, de 1665, que permitia a fundação de um convento de freiras em Salvador, a pedido dos "oficiais da Câmara, Nobreza e Povo" daquela capitania. Tal provisão sugere uma admissão, por parte da Corte, da existência de uma "nobreza baiana" (KRAUSE, 2014, p. 217).

Entretanto, é interessante mencionar que a importância das cidades ou vilas também constituia critério de "nobreza" para os magistrados locais, como sugere Francisco Craesbeeck. Ao se referir aos "homens bons" que, segundo o autor, eram todos aqueles que governavam as "vilas e lugares", o autor afirma que "Gozão huns destes de nobreza, e outros não, pois só a tem quando assistem ao governo politico das cidades, e villas notaveis; em que somente custumão servir os nobres" (CRAESBEECK, [17--?], p. 103). Com efeito, as "nobrezas" baianas e pernambucanas seiscentistas não possuiam o mesmo prestígio das elites camarárias do Porto, Coimbra ou Évora. Embora se comparassem, em temos de nobilitação, aos grupos dominantes de outras áreas do reino, como o Algarve (KRAUSE, 2014, p. 217).

Desse modo, nos principais municipios da monarquia portuguesa, as elites arrogavam para si o título de "nobreza da terra", a partir dos fundamentos do direito natural, segundo os quais a condição natural das coletividades era de possuírem, necessariamente, um grupo de "melhores", denominado seniors pars, a parte mais sã da sociedade. Consequentemente, de 
acordo com seu imaginário político-social, a distinção requerida pelas elites locais partia de uma lei impressa na própria natureza, e não, necessariamente, de uma categoria juridica positiva ou de uma nobreza de linhagem (HESPANHA, 2006, p. 2-13).

É nesse sentido, que compreendemos o fato de que em Pernambuco, Goa e Bahia, os homens notáveis arrogassem para si a qualidade de nobre, como um estatuto social que thes diferenciava dos homens comuns daquelas localidades. Nesse caso, o mais importante era "aparentar" a legitimidade da ocupação do cargo, ou do merecimento da mercê, perante a "opinião pública", por meio de demonstrações constantes de virtudes e comportamentos típicos da nobreza tradicional da Corte, evidenciados e difundidos por meio dos discursos memoriais que circulavam nos diversos territórios do reino.

\section{Participação: a partilha assimétrica da honra}

Tanto as elites locais quanto as elites da Corte compreendiam-se como parte de uma nobreza dividida em diversos graus que, junto ao monarca, compunham o topo da hierarquia político-social do reino. Desse modo, os discursos memoriais tendiam a defender a ideia de que a natureza do poder da nobreza encontrava-se indissociável da natureza do poder régio, buscando contribuir para a consolidação dos valores sobre os quais se assentava a sociedade, legitimando as posições hierárquicas e suas funções perante o público leitor.

A ideia de uma ordem político-social indivisivel, indisponivel e irrenunciável, que integrava as esferas superiores de poder por meio de valores e ações que thes eram próprias, contribuía para o sentimento de pertencimento ao corpo social e fortalecimento dos laços corporativos entre a nobreza e o monarca. Desse modo, a responsabilidade pela harmonia e conservação do reino era partilhada por todos os nobres, de acordo com seu grau de nobreza, e em conjunto com o rei. Acerca dessa lógica, Zurara, no prólogo de sua Chronica dos feitos do Conde Dom Pedro de Meneses (1651-1700), encomendada pelo rei Dom Afonso $\mathrm{V}$, afirma o seguinte:

[...] porem he minha tenção com ajuda da Santissima Trindade escrever em este volume os feitos que se fizerão na cidade de Cepta, depois a primamante foi tomada aos mouros p aqle magnanimo principe el Rey Dom João, e p.q o filosofo diz q cada cousa q move outra move em virtude do primeiro movedor, não ficara aqlle tão excellente Rey apartado de todo da Gloria, e louvor que aquele conde, e outros nobres Cavalleiros [...] naquella cidade ganharão, ne avera pequena parte deste honroso louvor este Rey Dom Affonso o Quinto (ZURARA, [1651-1700?], prólogo).

Zurara se vale da teoria aristotélico-tomista das causas segundas ${ }^{4}$ para explicar a origem da nobreza. Segundo afirma o autor, os feitos valorosos do conde e dos capitães em Ceuta haviam sido inspirados pelo rei Dom João I de Portugal, considerado o primeiro móvel, ou causa primeira das ações dos seus vassalos. Nesse sentido, o autor defende que apesar do seu discurso ser direcionado para o que aconteceu em Ceuta após a tomada da cidade por Dom João I, isto é, enquanto aquela conquista encontrava-se sob o governo de Dom Pedro de Meneses, as glórias alcançadas pelos feitos desse capitão e seus cavaleiros também eram compartilhadas pelo rei Dom João I, haja vista que o monarca era compreendido como causa da origem de tais glórias.

Em contrapartida, o rei Dom Afonso $V$, que havia encomendado a crônica, também não ficaria "apartado de todo" dos louvores merecidos pelo conde e seus homens, pois ao conservar a memória das façanhas desses notáveis, o monarca encorajava o público receptor do discurso a emular essa forma de conduta exemplar, necessária ao ideal de nobreza.

O prelado Cristóvão de Almeida, em sua Oraçam fúnebre nas exequias do Rey Dom Manoel (1665), defende um discurso semelhante ao de Zurara. Ao exaltar os feitos dos grandes exploradores portugueses a serviço do rei Dom Manuel I de

4 Segundo essa teoria, de inspiração aristotélica, nada se move por si além de Deus, a "causa primeira", que "move sem ser movido, e não pode ser diferente do que é". Diferentemente de Deus, tudo o que é criado e existe temporalmente necessita de uma causa motriz, que se move em uma determinada direção segundo sua natureza, e move outros sujeitos a partir de sua força, ou influência. 
Portugal, o autor exclama:

O Varoens Illustres! O Varoens Insignes! Rayos verdadeyramente daquelle Sol Resplandescente, \& Rey Serenissimo Dom Manoel para cujo valor foi o mundo todo pouco teathro. Vossos erão os golpes, mas Seus os triumphos, porq ainda que vòs obraveis as façanhas Elle ministrava as influencias (ALMEIDA, 1655).

Podemos perceber, tal como na crônica de Zurara, uma adaptação da teoria tomista das causas segundas. Por essa perspectiva, como já foi citado anteriormente, o monarca era considerado a causa motriz dos feitos dos seus vassalos, enquanto estes eram apenas sujeitos dessa mesma causa. Dessa forma, os nobres são representados como "raios" do rei enquanto Sol, que lhes encorajava a realizar "façanhas", isto é, descobrir novos territórios e rotas marítimas. No entanto, para o autor, mesmo os grandes feitos e as vitórias da nobreza eram possiveis apenas porque essas eram "influenciadas" pelo monarca, ou seja, as boas obras dos nobres eram vistas como efeitos de sua causa original, o rei.

A partir dessa mesma ótica, que compreende a existência da nobreza como efeito, ou reflexo do monarca, Miguel de São Tomás, em seu Sermam nas exequias do Rey de Portugal D. Affonso VI (1683), defende o seguinte:

Toda a dita, e ventura dos vossos vassallos assim Angelicos como humanos consiste em vos verem triunfante, e glorioso: ut congnoscant te; porque em quanto vos virem glorioso, não poderàõ sentir pena; e enquanto vos conhecerem triunfante, não poderàõ temer desgraça; que toda a sua dita, e ventura se cifra no logro da vossa vista triunfante, e glorioso. E a razão disto, além de outras, he, porque a dita dos vassalllos anda tão annexa à felicidade de seu Principe, que he impossivel, sendo o Principe ditoso, ser o vassalllo desgraçado; porque se a ventura se cifra nas estrellas, a mesma estrella, que he do Principe, he dos vassalllos estrella (SÃO TOMÁS, 1735, p. 14)

O argumento é iniciado pelo autor a partir de um tema em latim, retirado do Evangelho de São João, que pode ser traduzido da seguinte maneira: "E a vida eterna é esta: que te conheçam, a ti só, por único Deus" (Jo, 17:3). Com isso, o frei afirma que a felicidade dos "vassalos" de Deus, tanto dos homens quanto dos anjos, fundamentava-se no conhecimento e visão de Sua glória e triunfo.

Após definir o tema, Miguel de São Tomás resume-o em apenas uma frase: ut congnoscant te, ou seja, "que te conheçam". A partir disso, o frei é capaz de adaptar o tema bíblico, que primeiramente se referia a Deus, para o plano dos monarcas temporais. Nesse sentido, o bemcomum dos vassalos encontrava-se vinculado estreitamente aos exemplos retirados da boa fama dos monarcas. Em outras palavras, toda a ventura dos nobres dependia das demonstrações dos triunfos do rei, pois a felicidade do monarca possuía a mesma causa, ou origem, da felicidade dos vassalos, ou como coloca o frei: "se a ventura se cifra nas estrellas, a mesma estrella, que he do Principe, he dos vassalllos estrella".

Dessa forma, a "ventura" do monarca possuía a mesma origem da dos nobres. Segundo essa perspectiva, podemos dizer que a autoridade do rei e da nobreza possuía a mesma causa de origem, que nesse caso é representada por uma estrela, pois, como afirma o frei Luis da Silva, em sua oração fúnebre ao Marquês de Távora, escrita em 1674: "[...] as estrellas são o geroglifico da fidalguia [...]" (SILVA 1674, p. 16).

Podemos perceber nesses discursos, a recorrência da lógica da teoria aristotélica das quatro causas, que unia os monarcas e a nobreza em uma mesma cadeia de causa e efeito em relação às boas obras e à honra que delas provinham. Pode-se dizer que, segundo a lógica proposta pelos autores, os corpos físicos dos nobres eram a causa material das empresas, sua matéria, propriamente dita. A dignidade desses homens enquanto nobres era sua causa formal, isto é, aquilo que os ordenava para que assumissem determinada postura ou praticassem determinada ação. O monarca era a causa eficiente, o principio que atuava sobre os homens nobres para a consecução da obra. O bem-comum constituia sua causa final, ou seja, a finalidade de toda empresa a serviço do reino. Todas essas diferentes causas eram movidas por Deus, o primeiro móvel e causa de todas as coisas.

Ainda prosseguindo pela lógica de que o rei e a nobreza compartilhavam uma mesma causa, 
natureza fundamental, ou pelo menos que suas naturezas eram indissociáveis, gostariamos de retornar à crônica Zurara, no trecho em que ele reproduz uma parte da fala do rei Dom João I aos nobres que haviam ficado em Ceuta sob o comando do conde Dom Pedro de Meneses, animando-lhes a lutar para a defesa e manutenção da cidade:

[...] somente vos digo que se ponha ante vossos olhos quando $p$ ella pelleiares e peleíais polla mayor parte de minha horna, \& vossa ca posto q a mi como a vossa Cabeça esta honra seria atribuida vozoutros não ficais sem muy grande parte pq como muy bem sabeis assi se hão os vassallos com o sñor como os membros com o corpo pois como podera a Cabeça ser tirada que os membros ayão sua parte de sentimento, \& tanto mais quanto são chegados ao coração, certamente a mi não convem despender palavras em voz amoestar que sejeis fortes nas pelleias (ZURARA, [1651-1700?], p. 11).

Assim como nas três transcrições antecedentes, o rei e os nobres são representados como partes inseparáveis de um todo, no qual o monarca ocupava uma posição proeminente, a partir da qual ele coordenava as ações dos seus vassalos. No entanto, ao utilizar a lógica do funcionamento de um corpo humano para representar a relação entre o rei e seus vassalos, a transcrição que Zurara faz da fala de Dom João I oferece noções mais concretas acerca de como os homens seiscentistas compreendiam o ordenamento político-social.

Seguindo por essa perspectiva, as três metáforas utilizadas pelos autores supracitados evidenciam ideias semelhantes acerca da origem da nobreza. Cristóvão de Almeida retrata o monarca como o Sol, enquanto os cavaleiros eram os raios por ele propagados; Miguel de São Tomás afirma que a estrela que revelava a sorte do príncipe era a mesma que revelava a sorte dos vassalos; e Zurara representa o rei e seus vassalos como membros de um grande corpo, no qual o monarca era a cabeça. Todas as três metáforas podem ser relacionadas à soberania régia, pois todas apontam para o fato de que o poder do monarca era superior ao de todos os seus súditos, mas sem que esse poder fosse considerado distinto. Isso é dizer que o poder régio e o poder da nobreza se diferiam quanto ao grau e não quanto a sua natureza.
Deste modo, as ações valorosas dos súditos, a felicidade, e a honra do reino recaiam, em última instância, sobre o rei, sem que fosse necessária sua participação concreta na totalidade desses processos, bastando que ele mantivesse a unidade simbólica entre a instância régia e a nobreza, em uma relação de aliança e cooperação (NIETO SORIA, 1988, p. 128), haja vista que o monarca era sempre a causa motriz dos feitos dos seus vassalos, assim como da honra e do bemcomum do reino. Entretanto os nobres de alta categoria também poderiam ser a causa motriz, ou causa eficiente dos feitos virtuosos de nobres de menor prestígio, como podemos observar pelas palavras de João de Medeiros Correia, na dedicatória que fez ao governador de armas do Alentejo, António Luis de Meneses, em seu Panegirico a Andre de Alboquerque Ribafria (1661):

\begin{abstract}
Pellos effeitos se conhecem as causas, \& como V. Ex. foy o principio de nossa liberdade, assi na restituiçam deste Reino a seu legitimo Principe, como na facçam obrada em 14 de Janeiro do prezente anno de 1659. Aonde o grãde, Andre de Alboquerque, cujas virtudes relato, andou tam valente, como o era o General a que imitava, que foy a causa efficiente; com rezam restituo a $V$. Exc. o que de juro era seu, pois foi nomeado para este effeito por sua Mag. por Governador das Armas do Alentejo, escolhendoo entre outros dignissimos sogeitos, em occasiam em que hia arriscada nossa liberdade, ameaçada com todo o poder de Castella (CORREIA, 1661, dedicatória).
\end{abstract}

Ao afirmar que "pelos efeitos se conhecem as causas", Correia inicia sua dedicatória com um pressuposto básico da filosofia do PseudoDionísio Areopagita, retomada por São Tomás de Aquino. Segundo esse pensamento, um efeito sempre manifestava, de alguma maneira, a sua causa. Ou seja, a causa comunicava ao efeito certos aspectos de seu modelo original, manifestando-se a si mesma nesse efeito. Desse modo, o efeito deveria possuir, invariavelmente, certo grau de similitude em relação à causa (CASTRO, 2009, p. 111).

Assim sendo, Correia afirma que assim como António Luís de Menezes havia sido parte do principio da restituição do trono português a Dom João IV, ele também havia sido causa da 
vitória portuguesa na Batalha das Linhas de Elvas, em 1659, na qual servira como governador das armas do Alentejo. Dessa forma, ainda que o mestre de campo, general André de Albuquerque, homenageado pelo panegírico, houvesse "andado tão valente", a causa eficiente dos seus feitos havia sido António de Menezes, "general a quem imitava".

Prosseguindo por essa lógica, o autor sugere que ao dedicar o panegírico ao marquês, estava conferindo a António de Menezes aquilo que the pertencia por direito, haja vista que ele havia sido eleito entre os melhores fidalgos para proteger Portugal dos espanhóis. Nesse sentido, por meio da dedicatória, o autor estava restituindo os resultados do efeito à sua causa original, ou seja, a vitória da Batalha de Elvas ao marquês. Pode-se dizer. portanto, que a fama dos feitos virtuosos de André de Albuquerque era também compartilhada por António de Menezes, enquanto sua causa eficiente.

Ao representar o rei e a nobreza enquanto partícipes de um mesmo tipo de poder, em maior ou menor grau, e projetado progressiva e regressivamente por meio de relações de causa e efeito, os autores dos discursos representavam uma sociedade de natureza compósita, na qual o poder que emanava do monarca era repartido decrescentemente entre diversas instâncias, territórios e niveis hierárquicos de nobreza, ao mesmo tempo que legitimavam a soberania régia como indispensável para a garantia da unidade do reino. Desse modo, podemos dizer que a metáfora do corpo, proposta por Zurara, por sua larga difusão e antiguidade, compunha uma metáfora matriz, da qual se depreendiam as outras duas: a metáfora da estrela, de Miguel de São Tomás, e a do Sol, de Cristóvão de Almeida.

Isso posto, percebe-se que nos referidos discursos, as relações cabeça/membros, Sol/raios, e estrela-rei-vassalos, procuravam persuadir o público receptor de que os monarcas e os súditos compunham uma organização supraindividual, na qual todas as partes eram irredutiveis. O rei e os nobres partilhavam de um poder oriundo de uma mesma matriz, embora distribuido de maneira dispersa e hierarquizada. Assim sendo, essas metáforas cumpriam um importante papel na eficácia da conformação das condutas dos nobres, pois, se os vassalos eram parte do mesmo organismo que o rei, a honra individual de cada membro concorria para a honra do todo do corpo político-social, assim como a desonra individual também ocasionaria em prejuizo da integridade natural desse corpo.

Dessa forma, os autores dos discursos memoriais jamais poderiam contestar a hierarquia social em si, mas somente determinados vícios de costume dos estamentos superiores, assim como não se buscava dilatar o poder monárquico ou da nobreza, pois este já estava dado pela tradição. O que se pretendia era realinhar os homens notáveis à hierarquia, movendo-os às ações e costumes que lhes confirmavam enquanto nobreza (PÉCORA, 2008, p. 201)

Portanto, essas representações fundamentais da sociedade não eram utilizadas nos discursos memoriais apenas para mover o público receptor ao empreendimento de feitos valorosos, mas também para reprovar determinados comportamentos. Um exemplo disso é o questionamento que o desembargador António Moniz de Carvalho faz em sua Traduçam de huma breve conclusão e apologia da Justiça del Rey $N$. Senhor (1641), após descrever as evidências de tirania cometida por Filipe IV de Espanha contra o reino de Portugal: 5

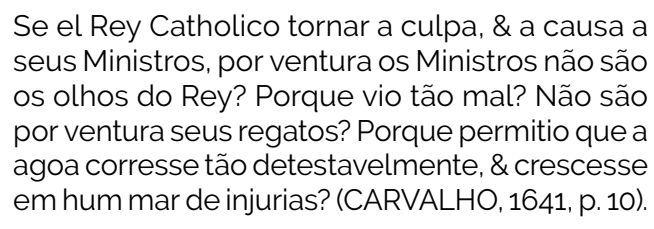

Esse questionamento possui uma lógica similar a dos trechos supracitados. Todavia, em vez de encorajar a realização de feitos valorosos, busca demonstrar a culpa de Filipe IV em relação às injustiças que, segundo ele, a Coroa espanhola

\footnotetext{
Para o autor, tais evidências eram os tributos abusivos e extraordinários, a venalidade de títulos, ofícios e comendas de ordens militares a pessoas indignas, a não observância das leis e foros de Portugal, a usurpação das armas e exércitos de Portugal para guerras estrangeiras e injustas, o desamparo das conquistas Portuguesas e os vários desmandos do Duque de Olivares, valido de Filipe IV (CARVALHO, 1641, p. 8-10).
} 
havia promovido contra o povo português. Em primeiro lugar, António Moniz afirma que os ministros eram os olhos do rei, isto é, deveriam dar notícias ao monarca acerca daquilo que ocorria em outros territórios, especificamente, Portugal. Em segundo lugar, o autor utiliza-se de uma metáfora na qual os ministros são representados como regatos, que tinham o rei como fonte, cuja função era ordenar os seus cursos.

A partir dessas metáforas, nota-se que António Moniz, assim como os autores citados anteriormente, representa o rei e seus ministros (nobreza) como partes de um todo indivisivel. Nesse sentido, as "injustiças" que haviam ocorrido em Portugal, durante o periodo em que Filipe IV esteve à frente das duas Coroas, não poderia ser "culpa e causa" apenas de seus ministros, mas também do monarca, que não soubera escolher seus oficiais, ou ainda que não havia se ocupado em ordená-los devidamente, permitindo que se acumulassem as queixas dos portugueses em relação ao seu governo.

Relacionando esse trecho aos anteriores, podemos dizer que, da mesma forma que a honra do corpo político-social era repartida por todos seus membros, ou pelo menos pelos membros mais notáveis, a desonra e a culpa por situações de injustiça também deveriam ser compartilhadas entre o monarca e os vassalos. Nessa partilha, o rei era aquele que ficaria com a maior parte dessa culpa, enquanto "fonte" da nobreza, pois se um bom exemplo de soberano inspirava e moralizava seus súditos, um mau exemplo só poderia ter o efeito contrário.

A metáfora do monarca enquanto Sol, tal como é utilizada por Cristóvão de Almeida, longe de representar um rei como senhor absoluto do reino, parece-nos expressar a ideia tomista de participação. Segundo o filósofo, aquilo que sofre influência dos raios solares não recebe a forma do próprio Sol, como se fosse outro Sol, mas sim a iluminação e o calor do Sol. Nesse sentido, tudo aquilo que é iluminado e aquecido pelo Sol participa de sua natureza, em diversos graus de similitude, haja vista que quanto mais distante um objeto se encontra do Sol, menos iluminação e calor ele recebe deste (CASTRO, 2009, p. 117). Sob essa ótica, todos os nobres possuiam uma similaridade em relação ao monarca, por participação em seu poder político, embora de forma reduzida, pois o rei se diferia dos demais nobres enquanto fonte de toda a nobreza. Assim sendo, quanto mais distante hierarquicamente do monarca, menos uma posição político-social receberia influência de sua nobreza e majestade.

Nesse sentido, as virtudes do monarca enquanto Sol não possuíam um caráter absolutista. A representação da onipresença do rei como astro solar não significava a concentração do poder político unicamente em sua figura, mas era operada por meio dos seus "raios solares", isto é, pelos oficiais régios dispersados pelos diversos territórios do reino, que gozavam de determinada autonomia para cumprir suas funções. Quanto à equidade e à justiça, assim como o Sol iluminava e aquecia os astros de maneira assimétrica, segundo suas posições no cosmos, o rei deveria respeitar a ordem natural da sociedade, dando a cada um o que the era de direito, segundo o seu estado.

É interessante notar que a imagem solar não servia exclusivamente para representar a pessoa real, mas também a outros membros da realeza, como se pode perceber no sermão fúnebre de Bernardo de Braga, citado anteriormente no presente artigo:

As outras mortes lamente a piedade pella luz
que se faltou asi na occasiam presente lamenta
a desgraça a luz q nos faltou à nòs; hua luz,
emula de toda a corrente do Sol, q se là se
vio o Ecclipse do Corpo Luminozo na Europa,
estamos padecendo as trevas na America, o
que traziamos a luz nas mininas dos olhos,
espeyo cristalino (BRAGA, 1651).

Nessa passagem, é possivel que o autor, ao representar o infante Dom Duarte como uma luz comparável àquela do Sol que, "eclipsado" na Europa, também deixava de iluminar a América, estivesse buscando evocar a imagem do corpo místico da monarquia, que concebia a organização territorial e política do reino como um único corpo, constituido de cabeça e membros (KANTOROWICZ, 1998, p. 133-134). 
Tal representação funcionava como mecanismo de educação das elites no espaço colonial ibérico e estava associada ao processo de formação do sentimento de pertença das localidades à monarquia. Haja vista que, segundo o imaginário lusitano seiscentista, todos os territórios da monarquia faziam parte do mesmo corpo mistico. Assim sendo, enquanto representantes do topo da hierarquia local e projeção da nobreza da Corte em Pernambuco, a "nobreza da terra" deveria demonstrar o seu luto pela ausência de Dom Duarte, corporificando a união do corpo místico do reino nas conquistas (LUZ, 2008, p. 166).

Laura de Mello e Souza também chama atenção para a metáfora do poder real enquanto Sol, utilizada por António Vieira para se referir às práticas administrativas nas conquistas. Nessa perspectiva, o monarca irradiava sua luminosidade "solar" aos representantes locais por meio dos regimentos, em contrapartida, tal luminosidade projetava áreas de sombras nos territórios do além-mar, nos quais os interesses metropolitanos se combinavam com as situações contingentes das localidades (SOUZA, 2006, p. 11-12).

Considerando-se que nossa interpretação privilegia as representações de nobreza nos discursos retórico-poéticos difundidos em Portugal e suas conquistas, diferentemente da abordagem de Laura de Mello e Souza, sugerimos uma análise alternativa da metáfora em questão:

A sombra quando o sol está no zênite, é muito pequenina, e toda se vos mete debaixo dos pés; mas quando o sol está no oriente ou no ocaso, essa mesma sombra se estende tão imensamente, que mal cabe dentro dos horizontes. Assim nem mais nem menos os que pretendem e alcançam os governos ultramarinos. Lá onde o sol está no zênite, não só se metem estas sombras debaixo dos pés dos principes, senão também dos de seus ministros. Mas quando chegam àquelas Índias, onde nasce o sol, ou a estas, onde se põe, crescem tanto as mesmas sombras, que excedem muito a medida dos mesmos reis de que são imagens (VIEIRA, 1689, p. 341-342).

Para Hansen, a crítica de Vieira à administração das conquistas deve ser compreendida, sobretudo, a partir da noção de subordinação ao "bem-comum". Partindo desse pressuposto, a metáfora de Vieira busca representar aquilo que os administradores das conquistas deviam reproduzir enquanto aquilo que já são, ou seja, "sombras da imagem do monarca", ao mesmo tempo que prescreve aquilo que eles devem ser, ou melhor, pretende persuadi-los a permanecer sendo aquilo que já são, não estendendo a sombra do rei, de que são imagens, além dos limites adequados (HANSEN, 2008, p. 269-270).

Lopes Sierra, citado anteriormente, também se utiliza do termo "sombras" em uma representação que faz da projeção do poder dos monarcas em seus oficiais ultramarinos, tecendo, tal como Vieira, uma crítica aos abusos de certos ministros que haviam usurpado a jurisdição do governadorgeral Afonso Furtado. Para o autor:

Quem, pois, transforma Tão benévolas ações em tirânicos estragos, Sabeis quem, a malícia dos homens que correspondem à matéria de que estão compostos, que é dos mesmos elementos, querendo Dominar a sombra do Principe, ou com seu poder, debaixo de aparentes justificativas, uns aos outros" (SIERRA, 1676, p. 195).

É possivel observar certa semelhança retórica entre os discursos de Sierra e de Vieira, ambos criticam a falta de concórdia entre os oficiais ultramarinos que, buscando os próprios interesses, negligenciam o bem-comum da Coroa. Desse modo, "exceder a imagem dos reis" e "querer dominar a sombra do Príncipe" representava a usurpação do poder real e a subversão da hierarquia e da ordem natural, o que significava, além de "tirania", falta de decoro em relação ao cargo ocupado e, portanto, um atentado contra a honra.

Ademais, o termo "sombras", como utilizado por António Vieira, significava "retratos dos homens" (VIEIRA, 1698, p. 340). Assim sendo, os governantes do ultramar deveriam ser retratos fiéis do rei, projetados pela mesma fonte de poder, representada pelo "Sol". Segundo essa interpretação, é possivel considerar que, assim como nos discursos citados anteriormente, os vassalos do monarca (mesmo nas conquistas) eram dotados de certa "nobreza", enquanto participes de um poder de mesma natureza. 


\section{Considerações finais}

Como aponta Hansen, as representações retóricas que remetem a uma concepção corporativa da organização político-social surgem nos discursos memoriais portugueses seiscentistas como unidade de integração do reino, que buscava ordenar as instituições e processos administrativos das conquistas lusitanas. Assim sendo, tais discursos reproduziam representações hierárquicas e práticas políticas da Corte nos territórios mais afastados, prescrevendo as posições sociais por meio de imagens, a partir das quais os leitores deveriam se reconhecer, persuadindo-lhes a permanecer em sua posição subordinada ao bem-comum do corpo-social (HANSEN, 2008, p. 200-210).

Em contrapartida, as próprias elites locais demandavam representações exemplares do poder político, esperando encontrar nos discursos um repertório de crenças básicas amplamente compartilhadas acerca dos poderes da nobreza e do poder régio, que lhes permitisse reconheceremse como parte integrante do topo hierárquico da organização político-social monárquica, com seus próprios critérios de antiguidade e clareza, adaptados às realidades locais. Desse modo, os discursos memoriais funcionavam como vias de mediação entre a monarquia e a opinião das elites acerca desta e estavam direcionados para responder às exigências tanto das elites locais, quanto das elites reinóis.

Segundo tal contexto, ainda que seja necessário um levantamento mais substancial de fontes documentais relativo às localidades, é possivel dizer que determinadas designações sociais como "principais", "melhores da terra" e "nobreza da terra" eram formuladas, pelas elites locais, a partir de um imaginário político-social que concebia a hierarquia social como natural e, portanto, tradicional. Dessa maneira, ainda que tais elites não conformassem uma nobreza à maneira da Corte, elas estavam apresentando um arranjo social tradicional, isto é, a distinção entre nobres e plebeus, por meio da inclusão de novos termos na linguagem politica da época, visando instituir e perpetuar as suas posições de preeminência no ordenamento hierárquico das conquistas.
Para completar o quadro que traçamos a partir dos discursos analisados, levantamos a hipótese de que tanto a nobreza natural do reino quanto as elites locais, compreendiam-se a partir da concepção aristotélico-tomista de participação. Considerando-se que, segundo esse pensamento, todo efeito possui, em maior ou menor grau, participação em sua causa, e sendo o monarca a verdadeira causa de todas as mercês, as elites consideravam-se corresponsáveis pela administração da monarquia, assim como as elites das localidades consideravam-se reflexos da Corte, por participação no corpo místico do reino.

Portanto, tais homens, os quais se distinguiam dos homens comuns, possuiam deveres morais, sociais, políticos e religiosos semelhantes, isto é, ainda que as diversas elites da monarquia não compusessem uma categoria social homogênea, possuíam certos valores em comum, indispensáveis para a legitimação da distinção social, como a honestidade, a honra, a prudência e a justiça.

\section{Referências}

ALMEIDA, Cristóvão de. Oraçam fúnebre nas exequias annuaes do Serenissimo Rey de Portugal Dom Manoel. Disse-a na Santa Casa da Misericordia desta cidade de Lisboa em 13 de Dezembro de 1655 o P. M. Fr. Christovam de Almeyda, Lisboa, na officina de Antonio Craesbeeck de Mello, 1665. Biblioteca Nacional de Portugal, livro não paginado.

ANDRADE, Francisco Eduardo de. A invenção das Minas Gerais: empresas, descobrimentos e entradas nos sertões do ouro da América portuguesa. Belo Horizonte: Autêntica Editora/Editora PUC Minas, 2008.

BíBLIA. N. T. Evangelho de São João. In: BíBLIA. Português. Biblia sagrada: contendo o antigo e o novo testamento. Tradução de João Ferreira de Almeida. Rio de Janeiro: Sociedade Bíblica do Brasil, 1966.

BICALHO, Maria Fernanda Baptista. Conquista, mercês e poder local: a nobreza da terra na América portuguesa e a cultura politica do Antigo Regime. Almanack Braziliense, São Paulo, n. 2, p. 21-34, 2005. https://doi. org/10.11606/issn.1808-8139.voi2p21-34.

BRAGA, Bernardo. Sentimentos publicos de Pernambuco na morte do Infante D. Duarte: assistindo o Mestre de Campo General de todo o Estado do Brasil Francisco Barreto, Governador das armas desta Capitania, com a camera \& mais Nobreza na Igreja de N.S. de Nazareth Quarta feira, seis de Abril de 1650: offerecidos a Magestade de El Rey Dom Joam Quarto de Portugal pello Padre Frey Bernardo de Braga lente de Theologia Dom Abbade de S. Bento de Pernambuco. Que orou nestes sentimentos, Lisboa: por Domingos Lopes Rosa, 1651. Biblioteca Nacional de Lisboa, livro não paginado. 
CARDIM, Pedro. Centralização política e Estado na recente historiografia sobre o Portugal do Antigo Regime. Nação e Defesa, Lisboa, n. 87, p. 129-158, 1998.

CARVALHO, António Moniz de. Traduçam de huma breve conclusão e apologia da Justiça del Rey N. Senhor, \& dos motivos de sua felice acclamação, que fez em Latim o Doutor Antonio Moniz de Carvalho Dezembargador da Relação do Porto, \& Secretario das duas Embaixadas aos Reynos de Suecia, \& Dinamarca impressa em a Cidade, \& Corte de Esthocolmia do mesmo Reyno de Suecia, Lisboa: por Jorge Rodriguez: a custa de Lourenço de Queirós, Livreiro do Estado de Bragança 1641.

CASTRO, R. C. G. Negatividade e Participação: A influência do Pseudo Dionísio Areopagita em Tomás de Aquino - Teologia, Filosofia e Educação. 2009. 192 f. Tese (Doutorado) - Curso de Educação, Faculdade de Educação da Universidade de São Paulo, Universidade de São Paulo, São Paulo, 2009

CORREIA, João de Medeiros. Panegirico a Andre de Alboquerque Ribafria. Com os elogios que a sua morte se fizeram. Escreveo o D. Joam de Medeyros Correa, Lisboa: na officina de Domingos Carneiro 1661. Biblioteca Nacional de Portugal.

CRAESBEECK, Francisco Xavier da Serra. Espelho da nobreza do Reyno de Portugal. Manuscritos Reservados, [17--?], p. 1. Biblioteca Nacional de Portugal.

FRAGOSO, J., GOUVÊA, M. F., BICALHO, M. F. B. Uma leitura do Brasil colonial. Bases da materialidade e da governabilidade no Império, Revista Penélope, [s. l.], n. 23, 2000, p. 67-88, 2000

HANSEN, João Adolfo. Para ler as cartas do Pe. Antônio Vieira. Teresa (USP), São Paulo, v. 8/9, p. 264-299, 2008. https://doi.org/10.11606/issn.2447-8997.teresa.2008.116740.

HANSEN, João Adolfo. Barroco, neobarroco e outras ruinas. Destiempos, México, v. 14, n. 3, p.169-215, 2008.

HESPANHA, António Manuel A mobilidade social na sociedade de Antigo Regime. Tempo, Niterói, v. 11, n. 21, p. 121-143, 2006. https://doi.org/10.1590/S141377042006000200009 .

HESPANHA, António Manuel. As estruturas políticas em Portugal na época moderna. In: TENGARRINHA, José (org.). História de Portugal. 2. ed. São Paulo: UNESP, 2001.

HESPANHA, António Manuel. História das Instituições: Épocas Medieval e Moderna. Coimbra: Almedina, 1982.

KANTOROWICZ, Ernst H. Os dois corpos do rei: um estudo sobre teologia política medieval. São Paulo: Cia das Letras, 1998.

KRAUSE, Thiago Nascimento. De homens da governança à primeira nobreza: vocabulário social e transformações estamentais na Bahia seiscentista. Revista de História, São Paulo, n. 170, p. 201-232, 2014. https:// doi.org/10.11606/issn.2316-9141.v0i170p201-232.

LUZ, Guilherme Amaral. Produção da concórdia: a poética do poder na América portuguesa (sécs. XVI-XVIII). Varia historia, Belo Horizonte v. 23, n. 38, p. 543-560, 2007. https://doi.org/10.1590/S0104-87752007000200017.
MONTEIRO, Nuno Gonçalo. 'Ethos' Nobiliárquico no final do Antigo Regime no final do Antigo Regime: poder simbólico, império e imaginário social. Almanack Braziliense, São Paulo, n. 2, p.4-20, 2005. https://doi. org/10.14195/2183-8925_19_11.

MONTEIRO, Nuno Gonçalo. O "ethos" da aristocracia portuguesa sob a dinastia de Bragança: algumas notas sobre a casa e o serviço ao rei. Revista de História das Ideias, Coimbra, v. 19, p. 383-402, 1997.

MONTEIRO, Nuno Gonçalo. Os concelhos e as comunidades. In: HESPANHA, António Manuel (Coord.). História de Portugal: o Antigo Regime (1620-1807). Lisboa: Editorial Estampa, 1998. v. 4.

NIETO SORIA, José Manuel. Apologia y propaganda de la realeza em los cancioneiros castellanos del siglo XV: Diseño literario de un modelo político. En La España Medieval, Madrid, n. 11, p. 185-221, 1988.

NIETO SORIA, José Manuel. Fundamentos ideológicos del poder real en Castilla (siglos XIII-XVI). Madrid: Eudema, 1988.

PÉCORA, Alcir. Teatro do Sacramento. São Paulo: Ed. Unicamp, 2008.

PERELMAN, C.; OLBRECHTS-TYTECA, L. Tratado da argumentação: a Nova Retórica. Tradução de Maria Ermantina Galvão. São Paulo: Martins Fontes, 1996.

PRETO, Antônio Gil. Sentimentos Pella morte do Principe Dom Theodosio Demostrados Pella Nobre Cidade de Goa nas Solemnissimas Exequias q the Fez em sua Sé Primacial aos 22 de Dezembro de 1654. Goa, 1654. Torre do Tombo.

SÃO TOMÁS, Miguel de. Sermam que prégou o Padre Mestre Fr. Miguel de S. Thomas nas exequias do serenissimo Rey de Portugal D. Affonso VI celebradas na Sé de Portalegre em 9 de Outubro de 1683, Lisboa: na Off. de Miguel Rodrigues, 1735, Biblioteca Nacional de Portugal.

SIERRA, Juan Lopes. Vida o Panegírico fúnebre al senor Affonso de Furtado Castro do Rio Mendonca. In: SCWARTZ, Stuart B.; PÉCORA, Alcir (org.). As Excelências do Governador: O Panegírico Fúnebre a D. Afonso Furtado, de Juan Lopes Sierra (Bahia, 1676). São Paulo: Companhia das Letras, 2002.

SILVA, Luis da. Oraçam funebre, que disse D. Frey Luis da Sylva no Convento de N. Senhora de Penha de França, nas exequias do Marquez de Tavora, Lisboa: Antonio Rodriguez d'Abreu, 1674. Biblioteca Nacional de Portugal.

SOUZA, Laura de Mello. O Sol e a Sombra: política e administração na América portuguesa do século XVIII. São Paulo: Companhia das Letras, 2006.

VIEIRA, Antônio. Sermões. Quarta parte. Lisboa: Oficina de Miguel Deslandes, 1689.

ZURARA, Gomes Eanes de. Chronica dos feitos do Conde Dom Pedro de Meneses primeiro Capitão que foi na cidade de Cepta, Lisboa, [1651-1700?], Manuscritos Reservados, Biblioteca Nacional de Portugal. 


\section{Endereço para correspondência}

Guilherme Amorim de Carvalho

CNB 04, Lote 02, apartamento 502.

Taguatinga, 72115-045

Brasilia, DF, Brasil 